\title{
CONCEPT OF "A CULTURAL IMPERIALISM" AND ITS MEDIA AND COMMUNICATION EMBODIMENT TODAY
}

\author{
Iuliia Gudova \\ ${ }^{1}$ Mrs., Ural Federal University, Russia, jgudova@mail.ru
}

\begin{abstract}
The cultural imperialism in the broadest sense is the domination of one country over another by means of culture. In the book "Culture and Imperialism" (1993) Edward Said has given a conceptual character to a notion of cultural imperialism and has proved theoretically intellectual approach realized by him in relation to the analysis of an imperialism and its demonstrations in culture. He understood two interconnected processes as the cultural imperialism: cultural domination and cultural expansion of one country into culture structure and cultural development of another country.

E. Said defined a phenomenon of "a cultural imperialism" as multilateral cultural suppression as a result of which the dominating culture forces out and subordinates to himself all manifestations of the subordinated culture - from high to local, from personal to public, from the system of values to consumer interests, from symbols and rituals before their imitations in mass art. Culture as integrity forms imperial feelings, thoughts and imperial imagination.
\end{abstract}

Today the cultural imperialism is investigated by Y. J. Dal, P. Golding, P. Harris, S.P. Mains, G. Munkler, H. Schiller, and others have given. They consider a cultural imperialism as a way of realization of the symbolical power which manifestations can be cultural submission of other people by means of advance of language of the mother country as state and language of the international communication (a communication imperialism), domination in production and distribution of a cultural product (a media imperialism), domination in financing of the cultural industries (an investment imperialism). New and easy to interpret definition of the cultural imperialism was elaborated by S.P. Mains: "The cultural imperialism is a process of disproportional influence on social practices and ideologies of one sociopolitical group on politically weaker and (often) less healthy groups".

The cultural imperialism can be directed to the outside world and can be directed to the remote regions of the country. This article is devoted to the phenomenon of internal cultural imperialism. The analysis of a cultural imperialism as a difficult system of the relations in the system "Center and Periphery" on principal directions of the social and cultural interaction of the present is a current scientific problem. We will consider an internal cultural imperialism on the example of a media and communication imperialism in modern Russia.

In the modern Russian media space, the capital's center broadcasts most of the information content to the regional periphery. Some Russian regions do not exchange news information, the entire information flow moves two-way: the capital - regions, regions - the capital. It is the Periphery that produces events that the Central media acquire the status of news. Such interpretation is produced by journalists trained to see events through the eyes of the Domination Center and to set up a communication chain through filters and processes events so that they correspond to the dominant pattern. For this purpose, regional correspondent points of the central mass media work in the Russian regions, and a learning system for representatives of 
central media in regions is organized through Moscow.

Keywords: cultural Imperialism, communication imperialism, media imperialism, E. Said, internal cultural imperialism.

\section{METHODOLOGY}

The notion of "cultural imperialism" was introduced into scientific context by E. Said in his book "Culture and Imperialism". According to the concept of E. Said, cultural imperialism clearly exists and manifests itself in the 20th century in the situation of postcolonialism, when empires and colonies in the classical historical and political notion practically do not exist, but some social communities continue to exert an extremely strong influence on others through cultural domination (Said, 1993, p. 10).

Summing up the ideas of many contemporary researchers of cultural imperialism, G. Munckler shows that imperial domination includes superiority in the four most important spheres of interstate interaction: political, economic, military and cultural. In accordance with this structure, G. Munckler identifies varieties of modern imperialism: "investment" (economic) imperialism, "network" (political) imperialism, and "cultural" imperialism (Munkler, 2015, p.68).

However, such representations do not fit into the understanding of culture as a system that permeates all social phenomena and processes when culture is inseparable from investment economic processes and how different networks are developing in modern society: trade, financial, information or transportation. From the point of view of the cultural-philosophical approach, cultural imperialism incorporates into all forms of social, economic and political interaction carried out from the position of imperial domination, that is, the predominant ownership and disposition of investment financial-economic, infrastructure transport, communication and institutional resources.

Another theorist of cultural imperialism, Johan Galtung, in his work The Structural Theory of Imperialism sharpens his attention on communication imperialism, which he views as one of the manifestations of cultural imperialism. Communicative imperialism, according to the scientist, is based on the domination of the Center in the world's communication networks and the translation of objects and ideas (Galtung, 1971, p. 94). In his view, the vertical nature of the division of labor in the field of communication/broadcasting has particular importance.

J. Galtung argues that, despite the triviality of the idea that for the high level of industrial (production) culture it is necessary to develop the technology of broadcasting and communication, meanwhile the most developed countries manage to achieve domination in this sphere. This is connected, in the opinion of J. Galtung, with the fact that the previous generation of means of translation and communication had the character of material values and could always be sold, sometimes even second-hand. The buyer of secondhand means of broadcasting and communication was, according to the scientist, Periphery as part of the overall vertical trade structure, together with the means of production (the sector of the economy), the means of destruction (the military sector) and the means of creativity (the cultural sector). Meanwhile, while Periphery bought traditional means of broadcasting and communication, the Center has long dominated the creation of space communication satellites (communications), developed telecommunications technologies and Internet commerce.

Another researcher of cultural imperialism Dal Jong Jin says that in the sphere of media, cultural imperialism has gone through several stages of its development (Dal, 2007, p. 761). Initially, the Center owned communication and information networks and determined exactly where it would be delivered and in which options in the first place, as well. The center was engaged in the direct production of all the broadcasted content. At the second stage, the Center began leasing out networks and financing local information broadcasting channels and began selling franchises for its content production.

From this point of view, the Communication Center is located where the production of original media content is located, which is distributed as samples and for which the franchise is sold. Where the franchise is bought - only the cultural Periphery because it is not independent and not creative in the production of content. At the present stage, the Center exercises control over media communication networks and their content through monitoring of financing and legislative regulation. The center is always busy with the production of norms, including the norms of the law, and the norms of taste, and the norms of morality. 
The consequence of this principle is a special combination of cultural and communication changes, and in particular, the production and delivery of news. We all know that the largest news agencies are in the hands of the countries that dominate the global world, use the communications networks controlled by the Center, and leased lines. What is not so well analyzed is how news from the dominant Center captures most of the news flow broadcast by the news media of the Periphery. According to the sociological data of J. Galtung, Periphery countries do not write or read about each other, especially about their neighbors abroad militarypolitical alliance, they read more about "their" Center, because the Periphery wants to know more about the " important "for her part of the world (Galtung, 1971, p. 95). In our opinion, the situation is similar in the modern Russian media space, when the capital center broadcasts most of the information content to the regional periphery. And some Russian regions do not exchange news information, the entire information flow moves two-way: the capital - regions, regions - the capital.

According to J. Galtung, another aspect of the vertical division of labor in the news business is that it is the Periphery that produces events that the Center turns into news (Galtung, 1971, p. 96). This is done by journalists trained to see events through the eyes of the Domination Center and to set up a communication chain that filters and processes events so that they correspond to the dominant pattern. For these purpose correspondent points of the central mass media work in the Russian regions, and a system of internships and training for representatives of local media is organized through the capital's center.

The latter concept refers us directly to cultural imperialism, the subtype of which, according to J. Galtung, is also scientific imperialism (Galtung, 1971, p. 97). The division of labor between teachers (metropolitan journalists) and students (journalists from the periphery) is very clear: it is not the division of labor as such (found in most knowledge transfer situations), but the location of teachers and students in the sociocultural geographic space. If the Center always provides teachers and criteria for a worthy journalist and journalism, the Periphery always provides students, and its journalists occupy a position apprentice to the capital. In the process of training, a sample of the realization of the tastes of imperialism is formed.

Neighboring regions in the Periphery always know for sure that nothing flatters the Center so much as having the right to encourage students. In professional interaction, the capital's journalism will always act as an exemplary model, and journalism from the Periphery can receive in response a modest strategy of the cultural experiment. In the course of cultural communication. Periphery represents for the Center the embodiment of the model of culture developed at the Center, regardless of whether the Center is internal or international. This serves to strengthen the Center in the status of the Center, as it will then continue to develop a culture model along with its translation, thus creating a lasting demand for the latest innovations.

To all this, it is necessary to add a brain drain, when the most creative 'raw' brains (students) and the original 'raw' texts/projects move from the Periphery to the Center and are 'handled' with sufficient benefit for the central source of imperial power, then the picture of cultural and communication imperialism becomes completely complete.

\section{RESULTS}

Cultural imperialism in modern Russia we can consider proceeding from the thesis of N.V. Zubarevich that in the cultural space of the modern Russian state there are simultaneously "four Russia" - the capital and megacities, industrial centers and monotowns, rural areas and small towns, regions of the North Caucasus, Altai and Tyva. The structure of mass communications is isomorphic to the structure of society and culture, it is a communicative subsystem of culture and society as a whole. The uneven development of cultural infrastructure is also considered in research by E. Trubina (Trubina, 2013, p. 237), V. Komova (Komova, 2014, 450), V. Novatorov (Novatorov, 2012, 75) confirming the idea of cultural imperialism and its internal character, with reference to the modern Russian state, drawing the boundary between the Center and the Periphery along the Moscow Ring Road.

Mass communications in modern Russia are carried out in such a way that the images of "proper", ideal, norms, dominant values are broadcast from Moscow to regions, and images of "real", "random", and imperfect from the Periphery to Moscow. "The content is becoming less journalistic and more agitational and propagandistic" (Tulupov, 2013, S.80.). Accordingly, in order to withstand this discourse, the center of journalistic education is shifting from regions to Moscow. In the regions there is a reduction in the recruitment of students for journalistic specialties in universities and a reduction in the departments of journalism, highly qualified specialists, and teachers in regional universities. This leads to the fact that the majorities of journalists in the country are learned and retrained in Moscow and Moscow universities. Local faculties and schools of journalism are losing resources and authority.

The functions of regional mass media are changing too. They should now provide information about the region, interesting not for residents within the region, but for power structures in the region and in Moscow. 
Independent media in the regions are being closed, only mass media serving local authorities remain. Local media should now inform the authorities in the region and in Moscow about how the regulatory matrix created in the capital is being implemented in the region. If the region corresponds to the ideals and norms of Moscow, then this is a successful region. The struggle for "success" in the eyes of Moscow becomes the content of the work of local media. Local television, print and radio play main role in creating a positive image of the region. Ideal of "social media" is utopian now. Meanwhile, regional publications, and above all literary journals, should be an important means of preserving a common all-Russian cultural space (Golovin, 2014, p. 106), a means of opposing those phenomena that we call internal cultural imperialism.

\section{CONCLUSION}

As we see, the theory of cultural imperialism, which arose in order to explain the socio-cultural inequality in relations between different countries in today's open global and media-organized world, also works productively to explain the relationship between the information center and the Periphery within a single taken state.

Internal cultural imperialism in modern Russia at the level of mass communications is manifested in the uneven development of journalistic education in the capital and on the periphery, in the reduction of the number of independent regional media, in the development of normative communication from the capital to the periphery, and presentation communication from the provinces to Moscow, competition between various regional media for the most successful image of the region in the eyes of Moscow. Literary and art magazines should continue to be published in the regions as an important communication tool for preserving the cultural unity of Russian territories.

The reported study was funded by RFBR according to the research project № 18-311-00273.

\section{REFERENCE LIST}

Dal Y. J., 2007. Reinterpretation of cultural Imperialism: emerging domestic market vs continuing US dominance. Mass Culture and Society, vol.29.

Galtung J., 1971. A Structural Theory of Imperialism. Journal of Peace Research. Vol. 8, 2.

Golovin Yu.A., 2014. Regional literary and art magazine in the Russian media system. Issues of theory and practice of journalism. № 4.

Komova V.A., 2014. Dichotomy "Capital - Province" in the Russian cultural space. The young scientist. No. $12(71)$.

Munkler H., 2015. Empires. The Logics of Domination all over the World: since Ancient Rome to the USA.

Novatorov V.E., 2013. Traditions and innovations in the cultural interchange of the center and regions. Bulletin of the Moscow State University of Culture and Arts. No. 3 (53).

Said E.W., 1993. Culture and Imperialism.

Sannikova T.O. 2012. Traditions and innovations in the processes of interaction between the capital and the province. Labyrinth. Journal of Social and Humanitarian Research. No. 3.

Trubina E.G., 2013. Center and periphery: between growth and development. Philosophical and literary magazine Logos. No. 4 (94).

Tulupov V.V., 2013. Regional journalism: today and tomorrow. Issues of theory and practice of journalism. No. 2.

Zubarevich N.V., 2010. Regions of Russia: inequality, crisis, modernization. 